ALVES, Yara Elizabeth. Práticas formativas das mulheres em privação de liberdade e das em situação de egressas do sistema prisional de Minas Gerais. 2021. 356p. Tese (Doutorado em Educação). Faculdade de Educação, Universidade Federal de Minas Gerais, Belo Horizonte, $2021 .{ }^{1}$

\title{
PRÁTICAS FORMATIVAS DAS MULHERES EM PRIVAÇÃO DE LIBERDADE E DAS EM SITUAÇÃO DE EGRESSAS DO SISTEMA PRISIONAL DE MINAS GERAIS
}

Training practices of women in deprivation of liberty and of in situations of egresses from prison system of Minas Gerais

ALVES, Yara Elizabeth ${ }^{2}$

\section{RESUMO}

Esta pesquisa objetiva analisar as práticas formativas das mulheres em privação de liberdade e das em situação de egressas do sistema prisional de Minas Gerais, como forma de estudar os seus efeitos para esse grupo social. A pesquisa contempla as discussões sobre a centralidade do trabalho e o seu princípio educativo, a formação histórica da classe trabalhadora e o advento da prisão-pena, a divisão sexual do trabalho e as relações sociais de sexo, os processos de socialização das pessoas em privação de liberdade e das em situação de egressas do sistema prisional, entre outras. O estudo foi realizado a partir da análise documental e da pesquisa de campo em duas unidades prisionais femininas, uma de gestão pública convencional, o Complexo Penitenciário Feminino, e a outra um Centro de Reintegração Social (CRS) administrado pela Associação de Proteção e Assistência aos Condenados (APAC). Nessas unidades foram aplicados 37 questionários e realizadas 10 entrevistas com as mulheres em cumprimento de pena privativa de liberdade. Observou-se que as participantes da pesquisa atribuíram, de forma geral, efeitos que consideram positivos às suas práticas formativas. Elas se referiram à remição de parte do tempo de execução da pena, à ocupação, remuneração pelo trabalho, socialização, bem como às oportunidades e expectativas de futuro. Foi possível perceber ainda que os efeitos dessas práticas estão relacionados aos próprios efeitos do processo de prisionização, sendo que os primeiros são mobilizados para, em alguma medida, minimizar os últimos. Evidencia-se a importância que as práticas formativas têm para as mulheres em privação de liberdade e indica-se que a oferta dessas deve ser ampliada e aprimorada num processo necessariamente simultâneo. Foram entrevistadas ainda 9 mulheres em situação de egressas do sistema prisional, sendo 6 acompanhadas pelo Programa de Inclusão Social de Egressos do Sistema Prisional (PrEsp). Verificou-se que os efeitos

\footnotetext{
${ }^{1}$ Orientador: Dr. Fernando Selmar Rocha Fidalgo. Professor do Departamento de Administração Escolar (DAE), da Faculdade de Educação da Universidade Federal de Minas Gerais (FaE/UFMG). Doutor em Educação pela Pontifícia Universidade Católica de São Paulo (PUC/SP). Mestre em Educação pela UFMG e Pedagogo pela Universidade Federal do Rio Grande (FURG/RS). E-mail: fernandos@fae.ufmg.br.

${ }^{2}$ Doutora e Mestre em Educação pela Faculdade de Educação da Universidade Federal de Minas Gerais (FaE/UFMG). Graduada em Pedagogia pela FaE/UFMG. Pesquisadora do Observatório Nacional do Sistema Prisional (ONASP). Email: yaraealves@gmail.com.
} 
sociológicos, psicológicos e biológicos produzidos pela prisão tendem a se manter no pós-cárcere. A tais efeitos se somarão ainda o preconceito e o estigma, também produzidos em certa medida pela própria prisão. Observou-se que no pós-cárcere as vivências das entrevistadas referem-se, sobretudo ao trabalho e às relações familiares. Para as mulheres em situação de egressas do sistema prisional o trabalho se constitui como um meio de subsistência própria e da família e como forma de resgate da autonomia, o que repercute, entre outras, no âmbito das relações afetivas. Ao mesmo tempo é na esfera do trabalho que as mulheres mais sofrem com a estigmatização. De forma geral, as entrevistadas acompanhadas pelo PrEsp avaliaram positivamente o Programa. Evidenciou-se ainda a importância do acesso dessas mulheres às políticas de proteção social. Espera-se que a pesquisa contribua para a produção do conhecimento sobre o tema e forneça subsídios à elaboração e implementação de políticas públicas setoriais.

Palavras-chave: Práticas formativas. Mulheres em privação de liberdade. Mulheres em situação de egressas do sistema prisional.

\section{ABSTRACT}

This research aims to analyze the training practices of women in deprivation of liberty and of in situations of egresses from the prison system of Minas Gerais, to study its effects for this social group. The research contemplates the discussions about the centrality of work and its educational principle, the historical formation of the working class and the advent of prison sentences, the sexual division of labor and the social relations of sex, the socialization processes of people in deprivation of freedom and those in situations of egress from the prison system, among others. The study was based on documentary analysis and field research, carried out in two female prison units, one with conventional public management, Complexo Penitenciário Feminino and the other with a Centro de Reintegração Social (CRS) administered by the Associação de Proteção e Assistência aos Condenados (APAC). In these units, 37 questionnaires were applied, and 10 interviews were carried out with women serving a prison sentence. It was observed that the research participants attributed, in general, effects that they consider positive to their training practices. They referred to the redemption of part of the time of execution of the sentence, occupation, remuneration for work, socialization, as well as opportunities and expectations for the future. It was also possible to see that the effects of these practices are related to the effects of the prison process, with the former being mobilized to some extent to minimize the latter. It highlights the importance that training practices have for women in deprivation of liberty and indicates that their offer must be expanded and improved in a necessarily simultaneous process. 09 women from the prison system were also interviewed, 06 of whom were accompanied by the Programa de Inclusão Social de Egressos do Sistema Prisional (PrEsp). It was found that the sociological, psychological, and biological effects produced by prison tend to remain in post-prison. In addition to these effects, prejudice and stigma are also added, which are also produced to some extent by the prison itself. It was observed that in the post-prison conditions, the interviewees' experiences refer, above all, to work and family relationships. For women in a situation of egress from the prison system, work constitutes a means of subsistence for themselves and the family and as a way of recovering autonomy, which has repercussions, among others, in the context of affective relationships. At the same time, it is in the sphere of work that women suffer most from stigmatization. In general, the interviewees accompanied by PrEsp evaluated the Program positively. The importance of these women's access to 
social protection policies was also highlighted. It is hoped that the research will contribute to the production of knowledge on the subject and provide subsidies for the elaboration and implementation of sectorial public policies.

Keywords: Training practices. Women in deprivation of liberty. Women in situations of egresses from the prison system.

Data da submissão: $26 / 07 / 2021$

Data da aprovação: 06/08/2021 